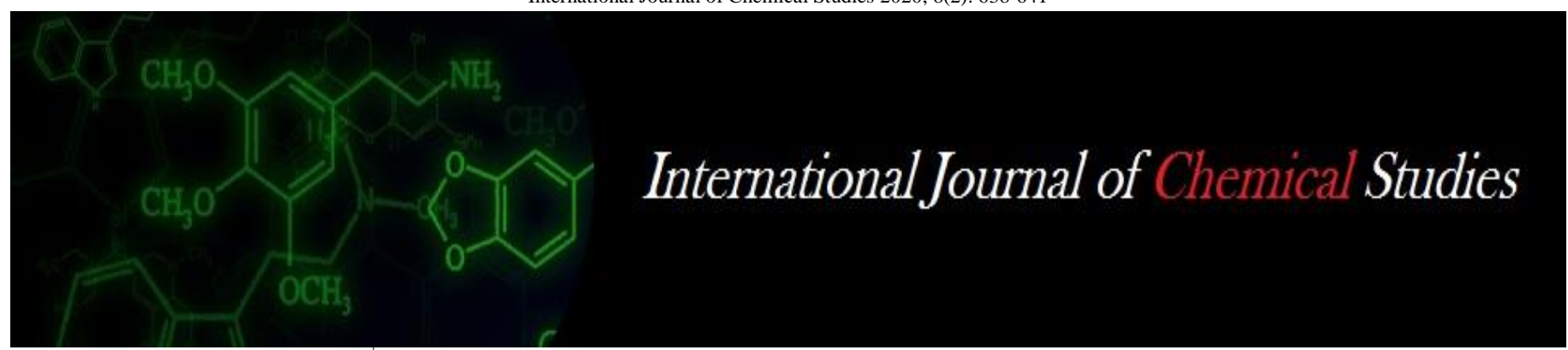

P-ISSN: 2349-8528

E-ISSN: 2321-4902

www.chemijournal.com

IJCS 2020; 8(2): 638-641

(C) 2020 IJCS

Received: 16-01-2020

Accepted: 18-02-2020

Babasaheb R Gunjale

Assistant Professor, SCSPA

College of Agriculture Ashti,

Beed, Vasantrao Naik

Marathwada Krishi Vidyapeeth,

Parbhani, India

Tukaram B Munde

Ph.D. Scholar, Department of

Agril. Economics and Statistics,

Dr. Panjabrao Deshmukh Krishi

Vidyapeeth, Akola,

Maharashtra, India

Gopal W Khorne

Ph.D. Scholar, Department of Agril. Economics and Statistics, Dr. Panjabrao Deshmukh Krishi Vidyapeeth, Akola,

Maharashtra, India

Corresponding Author: Babasaheb R Gunjale Assistant Professor, SCSPA College of Agriculture Ashti, Beed, Vasantrao Naik

Marathwada Krishi Vidyapeeth, Parbhani, India

\section{Comparative socio-economic analysis of soybean variety MAUS-71 VIS-À-VIS JS-335 of production in Beed district}

\author{
Babasaheb R Gunjale, Tukaram B Munde and Gopal W Khorne
}

DOI: $\underline{\text { https://doi.org/10.22271/chemi.2020.v8.i2j.8840 }}$

\begin{abstract}
Soybean (Glycine $\max (\mathrm{L}$.$) Merill) is a leguminous crop and belongs to family leguminoceae. It is$ originated in Chaina and it is a major oilseed crop in the world. Soybean is known as the "golden bean", "miracle crop" etc, because of its several uses. It is an excellent source of protein and oil. In India the area under soybean was 106.94 lakh hectares and production were 126.77 lack metric tonnes. In Maharashtra, soybean occupied an area 38.70 lakh ha area with production 48 lakh metric tonnes. The area under soybean in Beed district is 76.20 thousand hectars with the total production of 119.45 thousand metric tonnes and area under soybean in Ambajogai tahsil is 34.60 thousand hectars with total production of 61.80 thousand metric tonns in 2012-13. Multistage sampling design was adopted in selection of district, tehsil, villages and soybean growers. Soybean growers were stratified into two groups like MAUS-71 (48) and JS-335 (48). It was observed that 1.65 score of MAUS-71 grower was higher main occupational agriculture with compared to JS-335 soybean grower, about 1.41 score of JS335 grower had main occupation agriculture. Regarding total land holding of MAUS-71 growers were 2.27 hectare have 0.69 hectare area under soybean and total land holding of JS-335 soybean growers were 2.69 hectare have 0.84 hectare area under soybean. On an average, capital investment on commonly used asset was higher Rs. 355375.50 on MAUS-71 soybean farm with compared to Rs. 266777.50 on JS335 soybean farm, investment on commonly used asset was highest in MAUS-71 as compared to JS-335 soybean growers. Cropping patterns of MAUS-71 and JS-335 soybean growers the results revealed that gross cropped area was 4.60 hectares on JS-335 soybean farm followed by that of 4.15 hectares on MAUS-71 soybean farm. In kharif season the proportionate area under soybean was highest as 18.26 per cent on JS-335 and 16.63 per cent on MAUS-71 soybean farm. The net sown area on JS-335 soybean farm 55.87 per cent and MAUS-71 soybean farm 54.22 per cent, regarding double cropped area on MAUS-71 soybean farm was 45.78 per cent and JS-335 soybean farm was 44.13 per cent. In regard to cropping intensity it was observed that the highest cropping intensity was 184.44 per cent in MAUS-71 soybean farm followed by 178.99 per cent in JS-335 farm.
\end{abstract}

Keywords: Socio-economic, cropping pattern, tabular analysis, MAUS-71 and JS-335

\section{Introduction}

Soybean (Glycine max (L.) Merill) is a leguminous crop and belongs to family leguminoceae. It is originated in Chaina and it is a major oilseed crop in the world. Soybean is known as the "golden bean", "miracle crop" etc, because of its several uses. It is an excellent source of protein and oil. In India the area under soybean was 106.94 lakh hectares and production were 126.77 lack metric tonnes. In Maharashtra, soybean occupied an area 38.70 lakh ha area with production 48 lakh metric tonnes. The area under soybean in Beed district is 76.20 thousand hectars with the total production of 119.45 thousand metric tonnes and area under soybean in Ambajogai tahsil is 34.60 thousand hectars with total production of 61.80 thousand metric tonns in 2012-13. Kharif and Rabi are two main seasons in the district for crop production. In Kharif season hybrid jowar, bajra, soybean, tur, black gram, cotton and groundnut are the main crops while in rabi season wheat, gram and rabi jowar are the main crops cultivated in district. Sugarcane and vegetables are cultivated in the area where irrigation is available throughout the year. Cow and buffalo enterprises are supplementary, as well as symbiotic in characteristics with crop enterprises. To study socio-economic characteristics of the soybean growers.

Multi stage sampling design was adopted for selection of district, tehsil, villages as well as soybean producer of MAUS-71 and JS-335. In the first stage, Beed district was purposively 
selected on the basis of area under soybean production. In the second stage, Ambajogai tehsil of Beed district was selected on the basis of higher area under both soybean production varieties MAUS-71 and JS-335. In third stage, eight villages were selected from the selected tehsil on the basis of the highest area under soybean production. In the fourth stage, from each village, the separate list was prepared MAUS-71 and JS-335 varieties of soybean grower. From each of the village six farmers of MAUS-71 and JS-335 were randomly selected. Thus, from one village, twelve farmers were selected. In analytical techniques, the objective that is to know socio-economic characteristics of soybean grower was achieved by tabular analysis.

\section{Results and Discussion}

Socio-economic characteristics and cropping pattern of soybean growers are important aspects in soybean production. These aspects were expressed as under.

\section{Socio-economic characteristics of soybean grower}

Socio-economic characteristics of soybean growers were calculated and presented in Table 1. The results revealed that age was higher as 48.71 years variety JS-335 soybean farmer as compared to 46.75 year variety MAUS-71 soybean farmer, respectively because young generation group adopt new technology immediately as compared to age old group. In regard to education, it was observed that level of education in case of MAUS-71 soybean growers was higher up to high school 3.00 score while in case of JS-335 was educated up to 2.75 score. Because highly educated group of farmers adopt immediately new technology or improved packages of practices that's why higher education score in case of MAUS-
71 soybean grower. Regarding size of family, MAUS-71 soybean grower was 6.53 numbers and 1.27 number family workers and JS-335 grower was 7.15 numbers and 1.38 number family workers. Regards number of family members and family workers was greater in JS-335 as compared to MAUS-71 soybean growers, because due to richness or well to do family MAUS-71 soybean grower the number of family and worker also less in MAUS-71 as compared to JS-335 growers. It was observed that 1.65 score of MAUS-71 grower was higher main occupational agriculture with compared to JS-335 soybean grower, about 1.41 score of JS-335 grower had main occupation agriculture.

Regarding occupation score was highest in MAUS-71 that 1.65 score as compared to JS-335 growers because MAUS-71 soybean growers were the having more than one occupation were as in case of JS-335 soybean grower had only one agriculture occupation was that's why the occupation score more in MAUS-71 as compared to JS-335 soybean growers score. Regarding total land holding of MAUS-71growers were 2.27 hectare have 0.69 hectare area under soybean and total land holding of JS-335 soybean growers were 2.69 hectare have 0.84 hectare area under soybean. Regarding total land holding area under soybean crop was found highest in JS-335 as compared to MAUS-71 soybean growers even though MAUS-71 soybean growers well to do family because they adopt packages of practices with efficient management. The Milch animal and bullock pair in JS-335 soybean farm was higher to 2.25 and 1.23 number respectively, with compared to MAUS-71 soybean grower the Milch animal and bullock pair was observed to be 1.61 and 0.97 number respectively.

Table 1: Socio-economic characteristics of soybean growers

\begin{tabular}{|c|c|c|c|}
\hline \multirow{2}{*}{ S. No. } & \multirow{2}{*}{ Particulars } & \multicolumn{2}{|c|}{ Soybean farm } \\
\cline { 3 - 4 } & Age of farmer (year) & MAUS-71 & JS-335 \\
\hline 1. & Educational level (five quantum score) & 36.75 & 48.71 \\
\hline 2. & Family size (no.) & 6.53 & 2.75 \\
\hline 3. & Family worker (no.) & 1.27 & 1.15 \\
\hline 4. & Lccupational level (three quantum score) & 1.65 & 1.41 \\
\hline 5. & Land holding (ha.) & 2.27 & 2.69 \\
\hline 6. & Area under soybean (ha.) & 0.69 & 0.84 \\
\hline 7. & Milch animal (no.) & 1.61 & 2.25 \\
\hline 8. & Bullock pair (no.) & 0.97 & 1.23 \\
\hline 9. & Machinery (no.) & 0.65 & 0.41 \\
\hline 10. & Investment on milch animal (Rs) & 32755.23 & 40855.11 \\
\hline 11. & Investment on bullock pair (Rs) & 47225.12 & 42325.47 \\
\hline 12. & Investment on commonly used asset (Rs) & 355375.50 & 266777.51 \\
\hline 13. & Investment on irrigation structure (Rs) & 181830.13 & 154605.03 \\
\hline 14. & & \multicolumn{2}{c}{} \\
\hline
\end{tabular}

Regards to number of Milch animals and number of bullock were highest in JS-335 soybean growers as compared to MAUS-71 i.e. due to total land holding was more in JS-335 as well as number of family member and number of family workers were found more in JS-335 due to this they mention more Milch animal and bullock pair. On the contrary, capital investment milch animal was Rs. 32755.23 on the MAUS-71 soybean farm followed by the Rs 40855.11 on JS-335 soybean farm. In regard capital investment on milch animal was highest in JS-335 soybean growers as compared to MAUS-71 soybean growers. It is but natural because number of milch animals highest in JS-335 that's why capital investment on milch animals was found highest JS-335 soybean growers. Capital investment on bullock pair was higher Rs.47225.12 on the MAUS-71 farm with compared to Rs. 42325.47 on the JS-335 farm.
Regarding capital investment on bullock was observed highest in MAUS-71 as compared to JS-335 even though the number of bullock pair was more in JS-335 as compared to MAUS-71 this was due to the status symbol of MAUS-71 soybean growers. On an average, capital investment on commonly used asset was higher Rs. 355375.50 on MAUS-71 soybean farm with compared to Rs. 266777.50 on JS-335 soybean farm, investment on commonly used asset was highest in MAUS-71 as compared to JS-335 soybean growers because the MAUS-71 soybean growers were used mostly improved implement and machinery that's why investment on commonly used asset was more MAUS-71 as compared to JS335 soybean growers Similarly, capital investment on irrigation structure was higher Rs. 181830.13 on MAUS-71 soybean farm as compared to Rs.154605.03 on JS-335farm. Investment on irrigation structure was higher in MAUS-71 
soybean growers this was due to the richness of family or well to do family they can invest more on irrigation structure in JS335.Such results were found by Kakade, 1993.

\section{Cropping pattern of MAUS-71 and JS-335 soybean growers}

Cropping patterns of MAUS-71 and JS-335 soybean growers were estimated and presented in Table 2 the results revealed that gross cropped area was 4.60 hectares on JS-335 soybean farm followed by that of 4.15 hectares on MAUS-71 soybean farm. In kharif season the proportionate area under soybean was highest as 18.26 per cent on JS-335 and 16.63 per cent on MAUS-71 soybean farm.

Table 2: Per farm cropping pattern of soybean grower (Area in ha.)

\begin{tabular}{|c|c|c|c|c|c|}
\hline \multirow{2}{*}{ S. No. } & \multirow{2}{*}{ Particulars } & \multicolumn{2}{|c|}{ MAUS-71 } & \multicolumn{2}{|c|}{ JS-335 } \\
\hline & & Number & Percentage & Number & Percentage \\
\hline & Kharif & & & & \\
\hline 1 & Soybean & 0.69 & 16.63 & 0.84 & 18.26 \\
\hline 2 & Cotton & 0.32 & 7.71 & 0.38 & 8.26 \\
\hline 3 & Bajra & 0.31 & 7.47 & 0.33 & 7.17 \\
\hline 4 & KharifJowar & 0.39 & 9.4 & 0.35 & 7.61 \\
\hline 5 & Tur & 0.25 & 6.02 & 0.27 & 5.87 \\
\hline 6 & Maize & 0.17 & 4.1 & 0.21 & 4.57 \\
\hline \multirow[t]{3}{*}{7} & Black gram & 0.12 & 2.89 & 0.19 & 4.13 \\
\hline & Total & 2.25 & 54.22 & 2.57 & 55.87 \\
\hline & Rabi & & & & \\
\hline 8 & Rabi Jowar & 0.53 & 12.77 & 0.52 & 11.3 \\
\hline 9 & Wheat & 0.43 & 10.36 & 0.47 & 10.22 \\
\hline \multirow[t]{3}{*}{10} & Gram & 0.45 & 10.84 & 0.49 & 10.65 \\
\hline & Total & 1.41 & 33.98 & 1.48 & 32.17 \\
\hline & Summer & & & & \\
\hline 11 & Vegetable & 0.08 & 1.93 & 0.09 & 1.96 \\
\hline \multirow[t]{3}{*}{12} & Groundnut & 0.25 & 6.02 & 0.27 & 5.87 \\
\hline & Total & 0.33 & 7.95 & 0.36 & 7.83 \\
\hline & Annual & & & & \\
\hline 13 & Sugarcane & 0.09 & 2.17 & 0.11 & 2.39 \\
\hline \multirow[t]{2}{*}{14} & Other & 0.07 & 1.69 & 0.08 & 1.74 \\
\hline & Total & 0.16 & 3.86 & 0.19 & 4.13 \\
\hline 15 & Gross cropped area & 4.15 & 100 & 4.6 & 100 \\
\hline 16 & Net sown area & 2.25 & 54.22 & 2.57 & 55.87 \\
\hline 17 & Double cropped area & 1.90 & 45.78 & 2.03 & 44.13 \\
\hline 18 & Cropping intensity & 184.44 & & 178.99 & \\
\hline
\end{tabular}

The proportionate area under cotton, bajra, kharif jawar, tur, maize and black gram were 7.71 per cent, 7.47 per cent, 9.40 per cent, 6.02 per cent, 4.10 per cent and 2.89 per cent on MAUS-71 soybean farm, respectively. While area under cotton, bajra, kharif jawar, tur, maize and black gram was 8.26 per cent, 7.17 per cent, 7.61 per cent, 5.87per cent, 4.57 per cent and 4.13 per cent on JS-335 farm, respectively, In rabi season, the proportionate area under rabi jawar was highest as 12.77 per cent on MAUS-71 than that of 11.30 per cent on JS-335 soybean farm. The proportionate area under wheat and gram was 10.36 per cent and 10.84 per cent on MAUS-71 soybean farm, respectively. While area under wheat and gram was 10.22 per cent and 10.65 per cent on JS335 soybean farm, respectively. In summer season, proportionate area under groundnut and vegetable was 6.02 per cent and 1.93 per cent in MAUS-71 and groundnut and vegetables were 5.87 per cent and 1.96 per cent in JS-335 soybean farm. In annul proportionate area under sugarcane and other was 2.17 per cent and 1.69 per cent in MAUS-71 soybean farm, respectively, whiles area under sugarcane and other 2.39 per cent and 1.74 per cent in JS-335 soybean farm. The net sown area on JS-335 soybean farm 55.87 per cent and MAUS-71 soybean farm 54.22 per cent, regarding double cropped area on MAUS-71 soybean farm was 45.78 per cent and JS-335 soybean farm was 44.13 per cent. In regard to cropping intensity it was observed that the highest cropping intensity was 184.44 per cent in MAUS-71 soybean farm followed by 178.99per cent in JS-335 farm. It was inferred that soybean grower was using land both under kharif and Rabi intensively with irrigation facility in summer season. Because, the investment on irrigation structure in MAUS-71 soybean grower were more as compare to JS-335 soybean grower that's why MAUS-71 soybean grower efficiently manage the double cropped area than the JS-335 soybean grower. Due to this reason cropping intensity was more as compare to JS-335 soybean.

\section{Conclusions}

It was concluded that 1.65 score of MAUS-71 grower was higher main occupational agriculture with compared to JS335 soybean grower, about 1.41 score of JS-335 grower had main occupation agriculture. Regarding total land holding of MAUS-71growers were 2.27 hectare have 0.69 hectare area under soybean and total land holding of JS-335 soybean growers were 2.69 hectare have 0.84 hectare area under soybean. On an average, capital investment on commonly used asset was higher Rs. 355375.50 on MAUS-71 soybean farm with compared to Rs. 266777.50 on JS-335 soybean farm, investment on commonly used asset was highest in MAUS-71 as compared to JS-335 soybean growers because the MAUS-71 soybean growers were used mostly improved implement and machinery that's why investment on commonly used asset was more MAUS-71 as compared to JS335 soybean growers.

Cropping patterns of MAUS-71 and JS-335 soybean growers the results revealed that gross cropped area was 4.60 hectares 
on JS-335 soybean farm followed by that of 4.15 hectares on MAUS-71 soybean farm. In kharif season the proportionate area under soybean was highest as 18.26 per cent on JS-335 and 16.63 per cent on MAUS-71 soybean farm. The net sown area on JS-335 soybean farm 55.87 per cent and MAUS-71 soybean farm 54.22 per cent, regarding double cropped area on MAUS-71 soybean farm was 45.78 per cent and JS-335 soybean farm was 44.13 per cent. In regard to cropping intensity it was observed that the highest cropping intensity was 184.44 per cent in MAUS-71 soybean farm followed by 178.99 per cent in JS-335 farm.

\section{References}

1. Aski SH, Gotyal SH, Patil MB, Hanumanaikar RH. Knowledge and its relationship with personal, socioeconomic and psychological characteristics of sunflower growers of Bijapur district. Agric. update. 2010; 5(34):430-432.

2. Lekunze J, Antwi MA, Oladele OI. Socio-economic constraints to sunflower production on Bojanala farming community of the North-West province, South Africa, Life Sci. J. 2011; 8(2):502-506.

3. Nale VA. Economics of production of soybean varieties JS-335 vis-à-vis MAUS-81 in Marathwada region M.Sc. (Agri.) MAU, Parbhani, 2005.

4. Pawar ND, Patil HN, Bhosale TG. Economics of soybean cultivation in Western Maharashtra. J Maharashtra agril. University. 2000; 25(1):52-54.

5. Potekar GM. Economics of soybean crop in Parbhani district. Agresco Report submitted to Social Science Committee, MAU, Parbhani, 2001, 54-56.

6. Raskar BS, Bhoi PG. Comparative productivity of soybean (Glycine max) based cropping sequences. Indian J agric. Sci. 2000; 70(1):820-823. 